\title{
1 Carbohydrates and insulin resistance in clinical nutrition: 2 recommendations from the ESPEN Expert Group
}

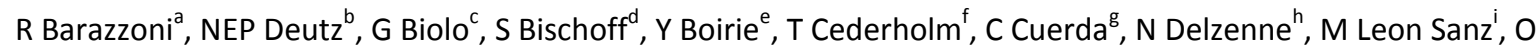

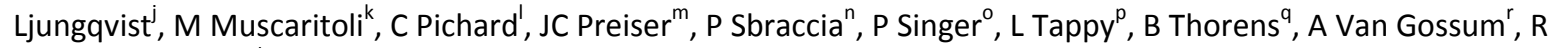
Vettor $^{\mathrm{s}}$, PC Calder ${ }^{\mathrm{t}}$

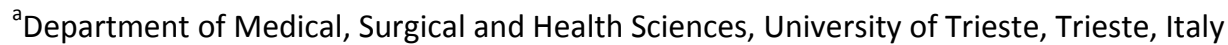
${ }^{\mathrm{b}}$ Center for Translational Research in Aging \& Longevity, Department of Health and Kinesiology, Texas A\&M University, College Station, TX, USA

'Department of Medical, Surgical and Health Sciences, Internal Medicine, University of Trieste, Trieste, Italy ${ }^{d}$ Department of Nutritional Medicine/Prevention, University of Hohenheim, Stuttgart, Germany

${ }^{\mathrm{e}}$ Department of Clinical Nutrition, $\mathrm{CHU}$ de Clermont-Ferrand, $\mathrm{CRNH}$, Université d'Auvergne, Clermont-Ferrand, France

${ }^{f}$ Clinical Nutrition and Metabolism, Department of Public Health and Caring Sciences, Uppsala University, and Department of Geriatric Medicine, Uppsala University Hospital, Sweden

${ }^{\mathrm{g}}$ Nutrition Unit, Hospital General Universitario Gregorio Marañón, Madrid, Spain

${ }^{\mathrm{h}}$ Department, Université Catholique de Louvain, Brussels, Belgium

'Department of Medicine, Complutense University, Madrid, Spain

${ }^{\mathrm{j}}$ Faculty of Medicine and Health, School of Health and Medical Sciences, Department of Surgery, Örebro

University, Örebro, Sweden

${ }^{k}$ Department of Clinical Medicine, Sapienza University of Rome, Rome, Italy

'Nutrition Unit, Geneva University Hospital, Geneva, Switzerland

${ }^{m}$ Department of Intensive Care, Erasme University Hospital, Brussels, Belgium

${ }^{n}$ Department of Systems Medicine, University of Rome Tor Vergata, Rome, Italy

${ }^{\circ}$ Department of Intensive Care, Institute for Nutrition Research, Rabin Medical Center, Beilinson Hospital, Sackler School of Medicine, Tel Aviv University, Israel

${ }^{\mathrm{p} D}$ Department of Physiology, Faculty of Biology and Medicine, University of Lausanne, Lausanne, Switzerland ${ }^{\mathrm{q}}$ Center for Integrative Genomics, University of Lausanne, Lausanne, Switzerland

'Gastroenterology Service, Hospital Erasme, Brussels, Belgium

sInternal Medicine Unit and Center for the Study and Integrated Treatment of Obesity, Department of Medicine, Padua University, Padua, Italy

${ }^{t}$ Faculty of Medicine, University of Southampton and NIHR Southampton Biomedical Research Centre, University Hospital Southampton NHS Foundation Trust and University of Southampton, Southampton, United Kingdom

Manuscript Endorsed by ESPEN Special Interest Group on Obesity

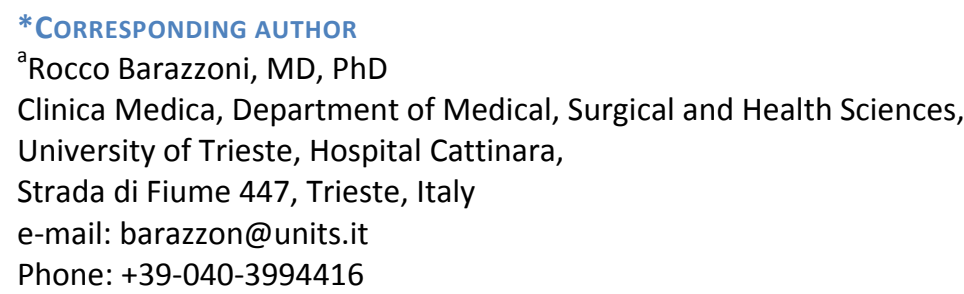


47

48

\section{Abstract}

Growing evidence underscores the important role of glycemic control in health and recovery from illness. Carbohydrate ingestion in the diet or administration in nutritional support is mandatory, but carbohydrate intake can adversely affect major body organs and tissues if resulting plasma glucose becomes too high, too low, or highly variable. Plasma glucose control is especially important for patients with conditions such as diabetes or metabolic stress resulting from critical illness or surgery. These patients are particularly in need of glycemic management to help lessen glycemic variability and its negative health consequences when nutritional support is administered. Here we report on recent findings and emerging trends in the field based on an ESPEN workshop held in Venice, Italy, 8-9 November 2015. Evidence was discussed on pathophysiology, clinical impact, and nutritional recommendations for carbohydrate utilization and management in nutritional support. The main conclusions were: a) excess glucose and fructose availability may exacerbate metabolic complications in skeletal muscle, adipose tissue, and liver and can result in negative clinical impact; b) low-glycemic index and high-fiber diets, including specialty products for nutritional support, may provide metabolic and clinical benefits in individuals with obesity, insulin resistance, and diabetes; c) in acute conditions such as surgery and critical illness, insulin resistance and elevated circulating glucose levels have a negative impact on patient outcomes and should be prevented through nutritional and/or pharmacological intervention. In such acute settings, efforts should be implemented towards defining optimal plasma glucose targets, avoiding excessive plasma glucose variability, and optimizing glucose control relative to nutritional support. 


\section{Introduction: carbohydrates, insulin resistance, and clinical} nutrition

Carbohydrates in the diet provide an essential metabolic fuel, commonly in the form of glucose. While necessary for life, excess or rapidly changing levels of glucose in the blood can lead to several health problems and contribute to the development of obesity, insulin resistance, and type 2 diabetes mellitus (T2D). Furthermore, poorly controlled glucose levels in critically ill patients or in those recovering from surgery can lead to glucose variability with hyper- and hypoglycemia, conditions that can impede recovery and can be fatal. In order to summarize recent research findings, share ideas, and discuss how emerging avenues of research may shape clinical nutrition recommendations and guidelines in the future, the authors of this manuscript participated in a workshop hosted by the European Society for Clinical Nutrition and Metabolism (ESPEN) on November $8^{\text {th }}$ and $9^{\text {th }} 2015$, in Venice, Italy. In this manuscript about glucose and glycemic control in clinical nutrition, we report on key concepts from workshop presentations. This report was prepared from a first draft based on summaries provided by each speaker, professionally edited, and further reviewed and revised in multiple rounds by all Faculty members. In this summary paper, we review how major metabolic organs use glucose and regulate its levels within the body, explain conditions that disrupt glycemic control, and discuss dietary and clinical nutrition guidelines for the treatment of conditions that feature dysglycemia.

Common digestible carbohydrates are classified as monosaccharides (glucose, fructose, and galactose), disaccharides (sucrose, lactose), or polysaccharides (starches, glycogen), based upon chemical structure [1]. Alternatively, carbohydrates are grouped based upon their digestibility and nutritional effect: the alpha bonds between glucose molecules in starch are easily broken down in digestion, whereas beta bonds in fibers are resistant to human digestive enzymes. Digestible carbohydrates break down and provide the body with monosaccharides for energy, while those that resist digestion are non-glycemic, but instead provide energy through fermentation in the colon by the gut microbiota. Carbohydrate quality and digestibility can influence postprandial plasma glucose concentration and the inflammatory response, which is now known to underlie the development of insulin resistance, metabolic syndrome, and T2D [2]. Foods with high glycemic index (GI) and glycemic load (GL) are associated with increased risk of such diseases [3-5]. Conversely, lowering dietary GI and GL 
can improve metabolic control [6-11]. Furthermore, increasing the protein-to-carbohydrate ratio can reduce glycemia [12], and inflammation can be tempered through dietary modification [13].

\section{Glucose metabolism in the organs}

Advances in research have shed light on the ways in which glucose interacts with a number of organ systems. Excess exposure of these organs to glucose as a result of hyperglycemia, as well as uncontrolled spiking of glucose levels after meals, can contribute to the deterioration of an individual's condition by causing metabolic derangements such as oxidative stress, tissue and systemic inflammation, and insulin resistance. This section summarizes the impact of glucose on major organs involved in substrate metabolism and utilization.

\section{Central Nervous System}

The relationship between glucose and the brain is important for the whole body. Glucose is the major physiological source of energy for the brain, and the brain senses glucose and carbohydrate levels throughout the body (Figure 1A, B). The brain utilizes hormones to signal to other organs (Figure 1B-E), communicate glucose status, and influence whole-body glucose homeostasis [14-16]. The impaired glucose homeostasis that occurs in T2D may be caused in part by early defects in central nervous system glucose sensing mechanisms [16].

\section{Skeletal muscle}

Skeletal muscle is a major contributor to whole-body glucose utilization, as glucose is a relevant fuel for the maintenance of skeletal muscle energy homeostasis (Figure 1A, D). However, excess glucose exposure can lead to muscle damage [17], which in turn has health and clinical consequences for the individual. Mechanisms of glucoseinduced tissue damage are complex and may vary in acute and chronic conditions. Common fundamental pathways causing muscle damage following exposure to excess glucose however include oxidative stress, inflammation, and insulin resistance, and it may alter tissue cell proliferation and differentiation [18]. Elevated glucose has been shown to cause mitochondrial damage and dysfunction in muscle cell culture experiments [19], thereby potentially leading to impaired tissue energy metabolism and substrate utilization. Through these 
combined mechanisms, hyperglycemia may enhance muscle protein catabolism leading to reduced lean body mass and strength [20-22]. In agreement with the above observations, people with T2D demonstrated activation of proinflammatory signaling pathways [23] and substantially enhanced protein breakdown [24] in skeletal muscle compared to healthy individuals. Muscle alterations are likely to become more clinically relevant when diabetesinduced hyperglycemia is associated with synergistic oxidative, pro-inflammatory, and insulin-desensitizing conditions such as aging or chronic and acute disease.

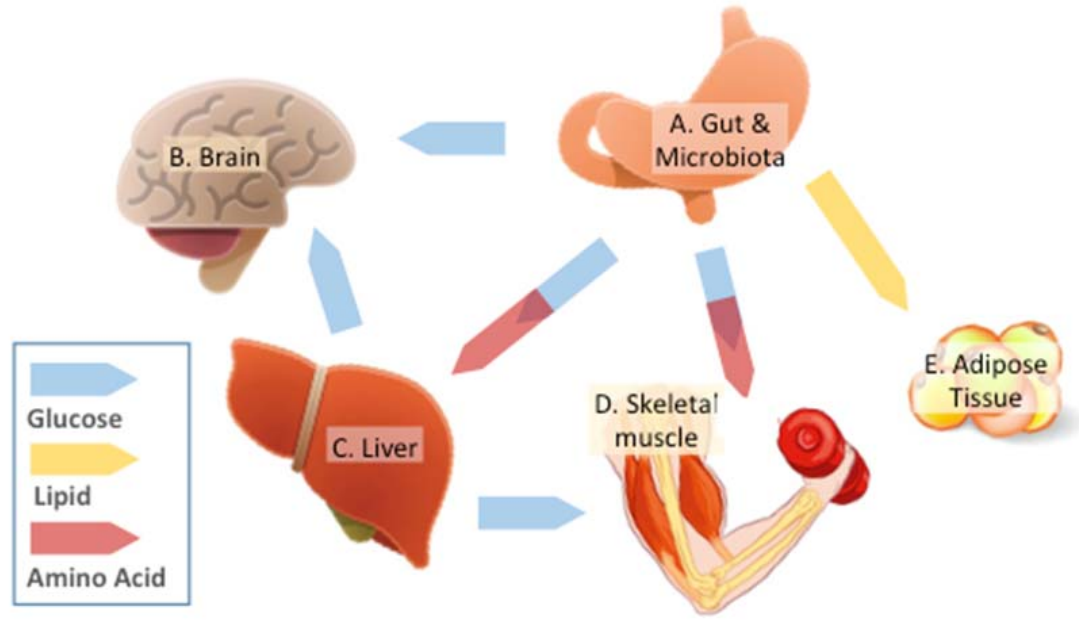

\section{Adipose tissue}

Adipose tissue plays a major role in maintaining wholebody metabolic homeostasis [25], but its accumulation is associated with adverse outcomes such as metabolic su syndrome and diabetes, cardiovascular events and several chronic diseases [26]. In recent years, research findings have revealed that qualitative changes in metabolic and endocrine characteristics of adipocytes (adiposopathy) mediate aspects of human disease. Metabolic research breakthroughs have uncovered ways that adipose tissue has substantial impact on energy balance, insulin resistance, inflammation and obesity-associated complications. Recently, differences between white and brown adipocytes have been described. White adipose tissue is the most abundant type of adipose tissue in human adults, and it

FIGURE 1: Summary overview of whole-body metabolic homeostasis. A. Digestible carbohydrate $(\mathrm{CHO})$ provide glucose from the gut, which also hosts functions as an energy store as well as a microbiota that may process otherwise indigestible complex $\mathrm{CHO}$. B. Glucose is modulator of whole-body substrate utilization the major energy source for the brain, which provides cues to the body about glucose availability. C. The liver produces glucose from non-glucose sources during fasting for tissue energy needs and may store glucose as glycogen. D. Skeletal muscle may provide amino acids to other organs for energy and functional needs during fasting as well as in catabolic and disease conditions. E. Adipose tissue mass may be enhanced by excess glucose availability; excess lipid substrates may conversely infiltrate skeletal muscle and liver tis 5 ues thereby contributing to insulin resistance and impaired glucose metabolism. 
and metabolism through its endocrine functions [27]. Brown adipose tissue has an increasingly recognized metabolic importance due to its higher mitochondrial content with high levels of uncoupling. These features lead to generation of heat (thermogenesis) associated with energy dissipation that may favor resistance to obesity and diet-induced weight gain [28]. Lower brown adipose tissue content has been described in people with obesity or T2D than in healthy individuals [29]. Experimental research has indicated that white adipose tissue can be converted into its more beneficial, metabolically active brown counterpart, and this process has become the target of intensive research [27, 30-33]. Irisin, an exercise-induced myokine, is thought to underlie the observed browning of adipose tissue in experimental models [30]. Although controversy surrounds the role of irisin in humans [34], this process may further underscore the potential importance of loss of muscle mass and function in the onset of obesity-associated metabolic complications.

Glucose modulates adipose tissue metabolism and mass both directly and indirectly by increasing insulin secretion and plasma concentration. Hyperinsulinemia is a key inducer of lipogenesis and adipose tissue expansion, and selective adipose tissue insulin receptor knockout may protect from fat tissue accumulation [35, 36] (Figure 1E). In agreement with the emerging view of inter-organ cross-talk to regulate metabolism, experimental models have demonstrated that glucose is able to re-direct stem cells derived from non-adipose tissues such as skeletal muscle to differentiate into ectopic adipocytes [37].

\section{Liver}

Interactions between carbohydrate and fat substrate availability may affect non-adipose tissues in the body by favoring ectopic lipid deposition [38]; non-alcoholic fatty liver disease (NAFLD) and non-alcoholic steatohepatitis (NASH) represent a relevant example of this negative interplay. NAFLD is an early indicator of insulin resistance and metabolic syndrome in people with obesity [39], triggered by inflammatory processes induced by overfeeding. Carbohydrates play a key role in the onset of NAFLD, with a negative impact for both excess glucose and fructose, whereas complex and non-digestible carbohydrates may be protective [40,41]. High glucose contributes to the onset of NAFLD also by enhancing circulating insulin, which in turn contributes to hepatic lipogenesis. Inflammation and pro-inflammatory signals are generated by excess fat accumulation $[26,42,43]$ and are also 
directly triggered by endotoxin translocation from the gut to the liver, with fructose being a major regulator of this process [44]. Underlying molecular mechanisms of liver damage are not fully understood but may involve the immune response and activation of immune signaling pathways that can cause liver damage and fibrosis [45-48]. Steatosis is reported to be ameliorated by intake of omega-3 polyunsaturated fatty acids (PUFAs) [49] and complex carbohydrates [50,51]; elements of the Mediterranean diet $[52,53]$ and the Asian diet $[54,55]$ may therefore prevent metabolic liver disease. NAFLD can also be combatted by the fostering of a healthy and diverse population of gut microbiota, as discussed below [44, 56-59].

\section{Gut and gut microbiota}

The gut plays central roles in the processing of carbohydrates and thereby influences glucose balance in the body (Figure 1A). Gut endocrine functions and the gut bacterial population (microbiota) are emerging key players in the regulation of intermediary metabolism. Unfavorable microbiota may contribute to the onset of obesity and metabolic syndrome mainly by triggering pro-inflammatory responses, and by favoring efficient nutrient absorption [60,61]. On the other hand, beneficial bacterial strains may result in protection from metabolic disease, and interaction with non-digestible dietary carbohydrates contributes to this effect. In particular, dietary fibers interact with the gut microbiota and may reduce inflammation and unfavorable metabolic responses, thereby also reducing hepatic steatosis [41, 62]. Gut microbiota-driven fermentation of non-digestible carbohydrates or prebiotics can decrease carbohydrate-induced blood glucose spikes that occur after a meal [63]. Probiotics may further modulate release of gut peptides including glucagon-like peptide 1 (GLP-1), also potentially contributing to limit obesity and its metabolic complications $(45,82)$. Fermentation of non-digestible carbohydrates also results in production of short chain fatty acids (SCFAs) that may play protective roles and reduce the risk for systemic and local disease including cancer. Obese individuals are reported to display metabolically unfavorable populations of gut microbes, and weight loss after gastric bypass surgery may shift this pattern towards one resembling normal weight individuals $[64,65]$. The possibility of harnessing microbiota to treat obesity and metabolic disease is under intensive investigation. Small-scale clinical studies of probiotic supplementation have found favorable changes to glucose and fat metabolism [61, 66-68]. Research has identified metabolically beneficial bacterial strains in the gut microbiota, like Lactobacillus, and Bifidobacterium, or 
Akkermansia, though their role as modulators of the host metabolism is still debated [69, 70]. Larger and longerterm human trials are still necessary before tailored probiotic use can be incorporated into official guidelines for the treatment of obesity and metabolic syndrome [61, 71].

\section{Fructose}

Glucose is the body's key form of energy and the most clinically relevant carbohydrate employed in patient nutritional support. For these reasons, glucose is the main focus of the current review. However, glucose is not the only simple sugar available through the diet. Fructose (as a monosaccharide or in the disaccharide sucrose) is also found in a variety of foods, but is processed differently by the body. Fructose has also been a focus of research, as it not only enters the diet through fruits but also is added to juices and other food products as a sweetener, and therefore is widely consumed. After absorption, fructose is metabolized by the liver and can be converted into glucose, lactate, and fatty acids. Fructose-induced hepatic lactate release is a unique feature and opposite to extrahepatic lactate flux to the liver for de novo glucose production. High-fructose diets have been reported to decrease insulin-mediated suppression of glucose production and to increase hepatic lipogenesis and plasma triglyceride concentrations [72], although recent meta-analyses have failed to confirm associations between fructose intake and several metabolic alterations potentially due to additional adaptive changes [73]. As introduced above, a stronger link has been established between fructose and non-alcoholic fatty liver disease (NAFLD), involving stimulation by fructose ingestion of pro-inflammatory signals reaching the liver from the gut $[44,46,74]$. Ingestion of a fructose-free diabetes-specific nutrition supplement formula (DSF) was shown to cause lower blood glucose concentrations in patients with diabetes than formulas with fructose [75], and physical activity has been shown to attenuate its deleterious effects on glycemic control [76]. However, as these effects of fructose are still debated [73], additional trials to determine whether fructose in particular should be avoided in the diet are necessary. 


\section{Recommendations for glycemic management and nutritional} support

\section{Obesity, metabolic syndrome, and diabetes}

\section{Diet and lifestyle}

Obesity and excess adiposity can lead to the development of glucose insensitivity, impaired insulin action, and inability to properly regulate glycemic variations. Although dietary recommendations aimed at weight loss have recently emphasized the importance of inducing energy deficits, at least in part independently of diet composition, high GI and GL foods are associated with metabolic disease risk and health complications [3-5]. Lowering dietary GI and GL may conversely improve these outcomes and benefit patients with obesity and diabetes [6-11]. Nondigestible carbohydrates may also provide beneficial metabolic effects. Soluble fiber is reported to decrease postprandial plasma glucose concentration and it may additionally decrease blood LDL-cholesterol concentration $[7,77]$. Insoluble fiber, especially cereal fiber, decreases the risk of T2D and cardiovascular disease [78]. High fiber intake is therefore recommended for people with diabetes or at risk of developing diabetes, including people with obesity and metabolic syndrome (i.e. the cluster of cardiometabolic risk factors including high waist circumference, high blood pressure, elevated blood glucose and dyslipidemia with high triglycerides and low HDL-cholesterol). Such nutritional recommendations (Tables 1,2 ) have been increasingly introduced by several health care organizations and are currently included in guidelines for patients with or at risk of developing T2D, and they are also appropriate for the management of plasma glucose concentration in type 1 diabetes (T1D) [79-81]. 
Table 1. Nutrition support guidelines and expert opinions for glycemic management in patients with diabetes mellitus types 1 and 2. T1D, type 1 diabetes; T2D, type 2 diabetes; IDF, International Diabetes Foundation; ADA, American Diabetes Association; NICE, National Institute for Health and Care Excellence; EASD, European Association for the Study of Diabetes; ESE, European Society of Endocrinology; SFAR, French Society of Anesthesia and Intensive Care; SRLF, Intensive Care Society (French language); SCCM, Society of Critical Care Medicine; ASPEN, American Society for Parenteral and Enteral Nutrition

\begin{tabular}{|c|c|c|c|c|}
\hline $\begin{array}{l}\text { Patient } \\
\text { population }\end{array}$ & Region & Source & Title & $\begin{array}{l}\text { Glucose } \\
\text { management } \\
\text { guideline }\end{array}$ \\
\hline \multirow[t]{3}{*}{ T1D } & Europe, Worldwide & IDF & $\begin{array}{l}\text { IDF } 2011 \\
\text { Postmeal glucose } \\
\text { guidelines [82] }\end{array}$ & $\begin{array}{l}\text { Measure postmeal } \\
\text { plasma glucose } 1-2 \\
\text { hours after a meal; } \\
\text { target for postmeal } \\
\text { glucose is } 9.0 \mathrm{mmol} / \mathrm{l} \\
\text { ( } 160 \mathrm{mg} / \mathrm{dL} \text { ) as long as } \\
\text { hypo-glycemia is } \\
\text { avoided. }\end{array}$ \\
\hline & US & ADA & $\begin{array}{l}\text { Standards of } \\
\text { Medical Care in } \\
\text { Diabetes-2016 } \\
\text { [79] }\end{array}$ & $\begin{array}{l}\text { Target premeal capillary } \\
\text { plasma glucose, } 80-130 \\
\mathrm{mg} / \mathrm{dL} \text { (4.4-7.2 } \mathrm{mmol} / \mathrm{L}) \text {. } \\
\text { Target peak postmeal } \\
\text { glucose }<180 \mathrm{mg} / \mathrm{dL} \\
\text { (10.0 } \mathrm{mmol} / \mathrm{L}) . \\
\text { Individualize goals, as } \\
\text { needed. }\end{array}$ \\
\hline & UK & NICE & $\begin{array}{l}\text { NICE NG17. Type } \\
1 \text { diabetes in } \\
\text { adults: diagnosis } \\
\text { and management } \\
2015 \text { [83] }\end{array}$ & $\begin{array}{l}\text { Aim for a fasting plasma } \\
\text { glucose level of 5-7 } \\
\text { mmol/L on waking and a } \\
\text { plasma glucose level of } \\
4-7 \text { mmol/L before } \\
\text { meals at other times of } \\
\text { day. }\end{array}$ \\
\hline \multirow[t]{2}{*}{ T2D } & Europe and US & ADA and EASD & $\begin{array}{l}\text { Management of } \\
\text { hyperglycaemia } \\
\text { in type } 2 \\
\text { diabetes: a } \\
\text { patient-centered } \\
\text { approach } 2012 \\
\text { [84]; Updated in } \\
\text { 2015 [85] }\end{array}$ & $\begin{array}{l}\text { The usual HbA1c goal } \\
\text { cut-off point is } 7 \% \text { ( } 53.0 \\
\text { mol/mol), but } \\
\text { individualized targets } \\
\text { are advised depending } \\
\text { on other health factors. }\end{array}$ \\
\hline & Europe and US & NICE & $\begin{array}{l}\text { NICE NG28. Type } \\
2 \text { diabetes in } \\
\text { adults: manage- } \\
\text { ment 2015[86] }\end{array}$ & $\begin{array}{l}\text { Aim for } \mathrm{HbA} 1 \mathrm{c} \text { goal of } \\
7 \% \text {, but individualized } \\
\text { target, as needed. }\end{array}$ \\
\hline
\end{tabular}


Table 2. Nutrition support guidelines and expert opinions for glycemic management in patients with stress metabolism or metabolic syndrome/obesity. ADA, American Diabetes Association; EASD, European Association for the Study of Diabetes; ESE, European Society of Endocrinology; SFAR, French Society of Anesthesia and Intensive Care; SRLF, Intensive Care Society (French language); SCCM, Society of Critical Care Medicine; ASPEN, American Society for Parenteral and Enteral Nutrition

\begin{tabular}{|c|c|c|c|c|}
\hline $\begin{array}{l}\text { Patient } \\
\text { population }\end{array}$ & Region & Source & Title & $\begin{array}{l}\text { Glucose management } \\
\text { guideline }\end{array}$ \\
\hline \multirow[t]{5}{*}{$\begin{array}{l}\text { Stress } \\
\text { metabolism/ } \\
\text { hospitalized } \\
\text { patients }\end{array}$} & $\begin{array}{l}\text { Europe and } \\
\text { US }\end{array}$ & $\begin{array}{l}\text { ADA, ESE, } \\
\text { others }\end{array}$ & $\begin{array}{l}\text { Management of } \\
\text { hyperglycemia in } \\
\text { hospitalized patients in non- } \\
\text { critical care setting; } \\
\text { Umpierrez } 2012 \text { [87] }\end{array}$ & $\begin{array}{l}\text { Premeal glucose target }<140 \\
\mathrm{mg} / \mathrm{dL}(7.8 \mathrm{mmol} / \mathrm{L}) \text { and random } \\
\text { glucose }<180 \mathrm{mg} / \mathrm{dL}(10.0 \\
\mathrm{mmol} / \mathrm{L}) \text { for most patients } \\
\text { hospitalized with non-critical } \\
\text { illness }\end{array}$ \\
\hline & Europe & $\begin{array}{l}\text { SFAR, } \\
\text { SRLF }\end{array}$ & $\begin{array}{l}\text { International } \\
\text { recommendations for } \\
\text { glucose control in adult non- } \\
\text { diabetic critically ill patients; } \\
\text { Ichai } 2010 \text { [88] }\end{array}$ & $\begin{array}{l}\text { Not possible to recommend a } \\
\text { single glucose threshold common } \\
\text { to all types of patients and } \\
\text { diseases. Avoid excessive } \\
\text { hyperglycemia ( }>10 \mathrm{mmol} / \mathrm{L} \text { ) in } \\
\text { critically ill patients }\end{array}$ \\
\hline & US & $\begin{array}{l}\text { ASPEN, } \\
\text { SCCM }\end{array}$ & $\begin{array}{l}\text { Guidelines for the provision } \\
\text { and assessment of nutrition } \\
\text { support therapy in the adult } \\
\text { critically ill patient; McClave } \\
2016 \text { [89] }\end{array}$ & $\begin{array}{l}\text { Target blood glucose range of } 140 \\
\text { or } 150-180 \mathrm{mg} / \mathrm{dL} \text { for the general } \\
\text { ICU population; ranges may differ } \\
\text { for specific patient populations } \\
\text { (cardio-vascular surgery, head } \\
\text { trauma) }\end{array}$ \\
\hline & US & $\begin{array}{l}\text { Expert } \\
\text { opinion }\end{array}$ & $\begin{array}{l}\text { Inpatient management of } \\
\text { diabetes and hyperglycemia; } \\
\text { Bogun } 2013 \text { [90] }\end{array}$ & $\begin{array}{l}\text { Good (mid-100 } \mathrm{mg} / \mathrm{dL} \text { range) but } \\
\text { not necessarily stringent }(<110 \\
\mathrm{mg} / \mathrm{dL} \text { ) glucose control is the } \\
\text { preferred approach in the ICU } \\
\text { setting }\end{array}$ \\
\hline & Canada & $\begin{array}{l}\text { Critical } \\
\text { Care } \\
\text { Nutrition }\end{array}$ & $\begin{array}{l}2015 \text { Clinical Practice } \\
\text { Guidelines [79] }\end{array}$ & $\begin{array}{l}\text { Avoid hyperglycemia (> } 10 \\
\mathrm{mmol} / \mathrm{L} \text { ) in all critically ill } \\
\text { patients. Use blood glucose } \\
\text { target of around } 8.0 \mathrm{mmol} / \mathrm{L} \text { (or } \\
7-9 \mathrm{mmol} / \mathrm{L} \text { ), rather than a more } \\
\text { stringent ( } 4.4 \text { to } 6.1 \mathrm{mmol} / \mathrm{L} \text { ) or } \\
\text { a more liberal target range (10 } \\
\text { to } 11.1 \mathrm{mmol} / \mathrm{L} \text { ) }\end{array}$ \\
\hline \multirow[t]{2}{*}{$\begin{array}{l}\text { Obesity/ } \\
\text { Metabolic } \\
\text { syndrome }\end{array}$} & Europe & EASD & $\begin{array}{l}\text { Evidence-based nutritional } \\
\text { approaches to the treatment } \\
\text { and prevention of diabetes } \\
\text { mellitus; Mann } 2004 \text { [81] }\end{array}$ & $\begin{array}{l}\text { No target glycemic range } \\
\text { recommended, but weight loss } \\
\text { and physical activity are } \\
\text { recommended to lessen insulin } \\
\text { resistance, thus lowering blood } \\
\text { glucose levels }\end{array}$ \\
\hline & $\begin{array}{l}\text { US and } \\
\text { Canada }\end{array}$ & $\begin{array}{l}\text { Expert } \\
\text { consensus } \\
\text { for } \\
\text { ASPEN, } \\
\text { SCCM }\end{array}$ & $\begin{array}{l}\text { Current strategies of critical } \\
\text { care assessment and therapy } \\
\text { of the obese patient } \\
\text { (hypocaloric feeding) } \\
\text { McClave } 2016 \text { [89] }\end{array}$ & $\begin{array}{l}\text { Glycemic targets not different } \\
\text { from those for all critically ill } \\
\text { adults; use frequent glucose } \\
\text { monitoring due to higher risk for } \\
\text { insulin resistance }\end{array}$ \\
\hline
\end{tabular}


Nutritional support can cause or exacerbate hyperglycemia, especially in obese and diabetic patients, and hyperglycemia is associated with higher morbidity and mortality [91, 92]. In the clinical nutrition setting, a burgeoning field of research is dedicated to designing nutritional support products for people with diabetes. Such products aim to limit glycemic variation after administration [93]. Diabetes-specific formulas (DSF) have many of the following ingredients in common: a) lower carbohydrate content than standard formulas (SFs); b) higher proportion of complex carbohydrates that are slowly digestible to reduce blood glucose spiking; c) modified maltodextrin, starch, fructose, isomaltulose, and sucromalt, rather than the maltodextrin, starch, and sucrose found in SFs [94]; d) fat content enriched in unsaturated fatty acids, especially monounsaturated fatty acids, in higher proportion than in SFs [87]; e) fiber content higher than in SFs [95].

Based on this available evidence, the ESPEN expert group endorses the utilization of DSFs for nutritional support of people with obesity and diabetes. When parenteral nutrition must be used, the risk of hyperglycemia in obese and diabetic patients can be reduced if the initial amounts of glucose provided in the TPN bag are limited to less than 2 $\mathrm{g} / \mathrm{kg} /$ day until proper glycemic control is observed [96]. With the use of enteral nutrition, the risk of hyperglycemia can be decreased by modification of the total amount and of the quality of carbohydrates used. Numerous shortand mid-term studies prove that enteral DSFs are associated with reduced postprandial blood glucose,

Acute states of metabolic stress often occur in the presence of disease. Such alterations may occur in individuals 
diabetes for reasons related or unrelated to the illness causing the metabolic stress. Critical illness and recovery from surgery are common clinical conditions requiring specific consideration.

\section{Nutrition for enhanced recovery in surgical patients}

Conventional thinking about the nutritional support of surgical patients has been challenged in recent years by a body of evidence demonstrating the relevant negative impact of metabolic complications on outcome, as well as the importance of nutrition to limit acute metabolic derangements. In particular, it has been clearly established that insulin resistance is a key mechanism behind developments of complications and delayed recovery in surgical patients [103]. Enhanced Recovery After Surgery $\left(\right.$ ERAS $\left.^{\circledR}\right)$ is a multi-modal perioperative care pathway shown to lead to major improvements in outcomes in patients undergoing abdominal surgery; many ERAS elements reduce insulin resistance, as summarized in recent guidelines [104]. Nutritional intervention may focus on overcoming the traditional concept of fasting as well as on the general indication for immune-nutrition to reduce morbidity. Traditional surgical practices have emphasized the importance of fasting overnight before the procedure, but new research has exposed this protocol as harmful to recovery [105]. Studies had originally indicated that a fixed amount of mixed complex carbohydrates can be administered orally as a drink on the evening before surgery and in the morning up to two hours before anesthesia, resulting in lower insulin resistance following surgical stress with a positive impact on recovery and length of hospital stay [106]. In general, as reflected in fasting guidelines for the past 20 years, evidence shows that clear fluids can be taken up to two hours before and that solids can be ingested up to six hours before surgery [107]. Efforts should be made to perform surgical procedures under the best attainable nutritional conditions, which may include nutritional support in combination with exercise before intervention [108]. Finally, the health care provider can prescribe pharmaco-nutrient support, including arginine and omega-3 fatty acids, to positively modulate immune response and limit inflammation to reduce morbidity, with particular regard to infectious complications. These can attenuate the inflammation and improve immune responses that may be impaired by surgery $[105,107]$, thereby lessening the risk for infection as well as insulin resistance and hyperglycemia [109]. 


\section{Glucose and nutritional support in critically ill patients}

Glucose is the preferential physiological substrate for the production of energy in emergency conditions, including the acute phase of critical illness. However, in the intensive care unit (ICU), acute metabolic stress commonly leads to insulin resistance and hyperglycemia. Avoiding high blood glucose concentrations with insulin infusion improves the outcomes (morbidity and mortality) of ICU patients in some studies, but not in others [110-112]. The optimal glycemic target is hence undefined and could differ between patients, time from injury, and setting. A strong association has also been reported between high glucose variability as well as hypoglycemia and poor outcomes in the critically ill [113-116]. There is, however, consensus on the importance of effectively and closely monitoring plasma glucose during critical illness to reduce variability. To this aim, automated systems for glucose control and near-continuous glucose monitoring may provide more reliable tools to stabilize glycemia, and their implementation is therefore recommended.

Glucose control may become more problematic while implementing effective nutritional treatment in acute critical illness. Enteral nutrition (EN) support has been shown to increase hyperglycemia risk in hospitalized patients. However, this increase is less important than for parenteral nutrition, as enteral feeding triggers an elevation of insulin known as the incretin effect [117-119]. When EN cannot be tolerated and parenteral nutrition (PN) is necessary, the high dextrose delivered by standard PN formulas can further exacerbate the stress-related hyperglycemia, even in non-diabetic critically ill patients $[91,92,96,115,120]$. Thus both calorie and glucose administration, particularly in early phases of critical illness, also commonly lead to higher insulin requirements to control glycemia, with higher risk for glycemic variability and potential stimulation of lipogenesis. Additional care should be taken to minimize these risks.

Furthermore, it is difficult to determine the optimal carbohydrate amount to administer to critically ill patients for several reasons. These include difficultly in assessing energy requirements, altered enteral absorption, and impaired suppression of endogenous glucose production. One study compared glucose-based energy to lipidbased energy provision in ICU patients and found that glucose was associated with trends for hyperglycemia, higher insulin requirements, enhanced lipogenesis, and no improvement in protein sparing [121]. DSFs containing higher proportions of fat and modified carbohydrates have not been extensively assessed in ICU patients, but 
recent data suggest that the use of these formulas improves glycemic control, and, in at least one study, this was shown to provide clinical benefit [100]. Further studies should address interactions between glucose, lipid, and protein substrates, as well as the potential metabolic impact of higher utilization of lipid substrates for energy provision.

Guidelines for nutritional strategy and composition of nutritional supplements have been published for practical indications to achieve glucose control in critically ill patients [79, 87-90] (Tables 1, 2). Suggestions from these published studies include: 1) intervene with EN support as soon as possible to limit caloric debt [122]; 2) minimize glycemic variability in patients who must take PN, with a target blood glucose of 90-150 mg/dl (5-8 mM) [123]; 3) avoid hypoglycemia as a result of these approaches. For the avoidance of hyperglycemia, predisposing factors should be identified [124-126], and administration of intravenous insulin to critically ill patients should be restricted when appropriate.

Based on the above considerations and the impact of calories on glucose metabolism and plasma concentrations, the issue of limiting calorie administration to critically ill patients, particularly those with obesity, has been considered [89]. Moderately hypocaloric feeding with high-protein content aimed at counteracting protein catabolism and muscle loss has been suggested in recent guidelines for critically ill obese patients $(22-25 \mathrm{kcal} / \mathrm{kg}$ of ideal body weight per day, $2 \mathrm{~g} / \mathrm{kg}$ protein of body weight if BMI is less than $40 \mathrm{~kg} / \mathrm{m}^{2}$, or 2.5 if $\mathrm{BMI}$ is greater than $40 \mathrm{~kg} / \mathrm{m}^{2}$ ) [89]. It should be pointed out that such recommendations are mainly aimed at minimizing metabolic abnormalities such as glucose variability and potential hyperlipidemia, rather than directly inducing weight loss. Additional research is desirable on optimal calorie provision for obese hospitalized patients with acute disease conditions requiring nutritional support. 


\section{Summary and conclusions}

While carbohydrates, which provide glucose to the body to support metabolism, are crucial to the diet, inappropriate intake can lead to hyperglycemia, hypoglycemia, and glycemic fluctuations that are harmful to health outcomes (Figure 2).

Excess glucose ingestion interacts with the gut and its microbiome and ultimately affects a number of organs including skeletal muscle, adipose tissue, and the liver. Excess glucose availability may induce expansion of adipose tissue and may favor ectopic fat deposition into liver and muscle tissues, which further exacerbates insulin resistance and glycemic imbalances. Insulin resistance is associated with, and can promote progression of, metabolic syndrome and eventually T2D, and it represents a factor contributing to hyperglycemia, glucose variability, and poor outcomes in the critically ill or those recovering from surgery.

Optimal nutritional support for patients with obesity and T2D should limit glucose provision, and plasma glucose should be carefully monitored in order to avoid harmful glucose fluctuations. In the surgical situation, preoperative fasting should be avoided as part of ERAS protocols to optimize outcomes, particularly in abdominal surgical patients. In critical illness, limiting glucose content in enteral and parenteral nutrition formulas may provide benefits, although safety of higher lipid administration should also be assessed. It should be finally recognized that more high-quality trials specifically addressing optimal enteral and parenteral nutrition compositions aimed at avoiding or minimizing clinical consequences of insulin resistance and hyperglycemia are needed for optimal clinical recommendations in these important areas of patient treatment.

\section{Acknowledgment}

The authors thank Dr. Cecilia Hofmann (C. Hofmann \& Associates, Western Springs, IL, USA) for her capable assistance with writing, reference management, and editing the manuscript. 


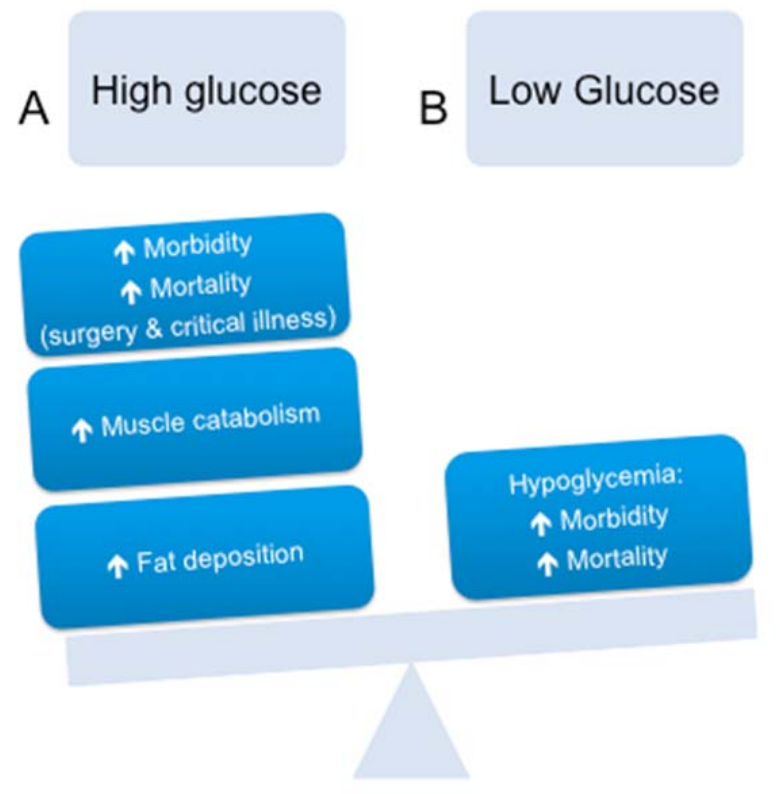

Figure 2. Consequences of glucose imbalance. A. Hyperglycemia (elevated blood glucose) may contribute to enhance adiposity and to muscle catabolism; in addition, hyperglycemia favors complications in acute disease conditions including surgery and critical illness. B.

Hypoglycemia (low blood glucose) can be fatal, especially in critically ill patients. Glycemic variability with uncontrolled swings in blood glucose towards both hyperglycemia and hypoglycemia is associated with poor outcomes after surgery and can be fatal to those in critical conditions. 
[1] Hojsak I. 1.3.4 Digestible and non-digestible carbohydrates. 1.3 Nutritional needs. World Rev Nutr Diet2015. p. 46-50.

[2] Buyken AE, Goletzke J, Joslowski G, Felbick A, Cheng G, Herder C, et al. Association between carbohydrate quality and inflammatory markers: systematic review of observational and interventional studies. Am J Clin Nutr 2014;99(4):813-33.

[3] Barclay AW, Petocz P, McMillan-Price J, Flood VM, Prvan T, Mitchell P, et al. Glycemic index, glycemic load, and chronic disease risk--a meta-analysis of observational studies. Am J Clin Nutr 2008;87(3):627-37.

[4] Bhupathiraju SN, Tobias DK, Malik VS, Pan A, Hruby A, Manson JE, et al. Glycemic index, glycemic load, and risk of type 2 diabetes: results from 3 large US cohorts and an updated meta-analysis. Am J Clin Nutr 2014;100(1):21832.

[5] Livesey G, Taylor R, Livesey H, Liu S. Is there a dose-response relation of dietary glycemic load to risk of type 2 diabetes? Meta-analysis of prospective cohort studies. Am J Clin Nutr 2013;97(3):584-96.

[6] Ajala O, English P, Pinkney J. Systematic review and meta-analysis of different dietary approaches to the management of type 2 diabetes. Am J Clin Nutr 2013;97(3):505-16.

[7] Livesey G, Tagami H. Interventions to lower the glycemic response to carbohydrate foods with a low-viscosity fiber (resistant maltodextrin): meta-analysis of randomized controlled trials. Am J Clin Nutr 2009;89(1):114-25.

[8] Joslowski G, Halim J, Goletzke J, Gow M, Ho M, Louie JC, et al. Dietary glycemic load, insulin load, and weight loss in obese, insulin resistant adolescents: RESIST study. Clin Nutr 2015;34(1):89-94.

[9] Keith M, Kuliszewski MA, Liao C, Peeva V, Ahmed M, Tran S, et al. A modified portfolio diet complements medical management to reduce cardiovascular risk factors in diabetic patients with coronary artery disease. Clin Nutr 2015;34(3):541-8.

[10] Farvid MS, Homayouni F, Shokoohi M, Fallah A, Farvid MS. Glycemic index, glycemic load and their association with glycemic control among patients with type 2 diabetes. Eur J Clin Nutr 2014;68(4):459-63.

[11] Gibbs M, Harrington D, Starkey S, Williams P, Hampton S. Diurnal postprandial responses to low and high glycaemic index mixed meals. Clin Nutr 2014;33(5):889-94.

[12] El Khoury D, Brown P, Smith G, Berengut S, Panahi S, Kubant R, et al. Increasing the protein to carbohydrate ratio in yogurts consumed as a snack reduces post-consumption glycemia independent of insulin. Clin Nutr 2014;33(1):29-38.

[13] Adamsson V, Reumark A, Marklund M, Larsson A, Riserus U. Role of a prudent breakfast in improving cardiometabolic risk factors in subjects with hypercholesterolemia: a randomized controlled trial. Clin Nutr 2015;34(1):20-6.

[14] Steinbusch L, Labouebe G, Thorens B. Brain glucose sensing in homeostatic and hedonic regulation. Trends Endocrinol Metab 2015;26(9):455-66.

[15] Thorens B. Sensing of glucose in the brain. Handb Exp Pharmacol 2012(209):277-94.

[16] Thorens B. Brain glucose sensing and neural regulation of insulin and glucagon secretion. Diabetes Obes Metab 2011;13 Suppl 1:82-8.

[17] Lopez Teros MT, Ramirez CF, Aleman-Mateo H. Hyperinsulinemia is associated with the loss of appendicular skeletal muscle mass at 4.6 year follow-up in older men and women. Clin Nutr 2015;34(5):931-6.

[18] Barazzoni R, Zanetti M, Gortan Cappellari G, Semolic A, Boschelle M, Codarin E, et al. Fatty acids acutely enhance insulin-induced oxidative stress and cause insulin resistance by increasing mitochondrial reactive oxygen species (ROS) generation and nuclear factor-kappaB inhibitor (IkappaB)-nuclear factor-kappaB (NFkappaB) activation in rat muscle, in the absence of mitochondrial dysfunction. Diabetologia 2012;55(3):773-82.

[19] Elkalaf M, Andel M, Trnka J. Low glucose but not galactose enhances oxidative mitochondrial metabolism in C2C12 myoblasts and myotubes. PLoS One 2013;8(8):e70772.

[20] Kalyani RR, Metter EJ, Egan J, Golden SH, Ferrucci L. Hyperglycemia predicts persistently lower muscle strength with aging. Diabetes Care 2015;38(1):82-90.

[21] Kalyani RR, Tra Y, Egan JM, Ferrucci L, Brancati F. Hyperglycemia is associated with relatively lower lean body mass in older adults. J Nutr Health Aging 2014;18(8):737-43.

[22] Lee CG, Boyko EJ, Barrett-Connor E, Miljkovic I, Hoffman AR, Everson-Rose SA, et al. Insulin sensitizers may attenuate lean mass loss in older men with diabetes. Diabetes Care 2011;34(11):2381-6. 
[23] Andreasen AS, Kelly M, Berg RM, Moller K, Pedersen BK. Type 2 diabetes is associated with altered NF-kappaB DNA binding activity, JNK phosphorylation, and AMPK phosphorylation in skeletal muscle after LPS. PLoS One 2011;6(9):e23999.

[24] Pupim LB, Flakoll PJ, Majchrzak KM, Aftab Guy DL, Stenvinkel P, Ikizler TA. Increased muscle protein breakdown in chronic hemodialysis patients with type 2 diabetes mellitus. Kidney Int 2005;68(4):1857-65.

[25] Rosen ED, Spiegelman BM. What we talk about when we talk about fat. Cell 2014;156(1-2):20-44.

[26] de Ferranti S, Mozaffarian D. The perfect storm: obesity, adipocyte dysfunction, and metabolic consequences. Clin Chem 2008;54(6):945-55.

[27] Stanford KI, Middelbeek RJ, Goodyear LJ. Exercise Effects on White Adipose Tissue: Beiging and Metabolic Adaptations. Diabetes 2015;64(7):2361-8.

[28] Bartelt A, Heeren J. Adipose tissue browning and metabolic health. Nat Rev Endocrinol 2014;10(1):24-36.

[29] Vernochet C, Damilano F, Mourier A, Bezy O, Mori MA, Smyth G, et al. Adipose tissue mitochondrial dysfunction triggers a lipodystrophic syndrome with insulin resistance, hepatosteatosis, and cardiovascular complications. FASEB J 2014;28(10):4408-19.

[30] Bostrom P, Wu J, Jedrychowski MP, Korde A, Ye L, Lo JC, et al. A PGC1-alpha-dependent myokine that drives brown-fat-like development of white fat and thermogenesis. Nature 2012;481(7382):463-8.

[31] Stanford KI, Middelbeek RJ, Townsend KL, Lee MY, Takahashi H, So K, et al. A novel role for subcutaneous adipose tissue in exercise-induced improvements in glucose homeostasis. Diabetes 2015;64(6):2002-14.

[32] Trevellin E, Scorzeto M, Olivieri M, Granzotto M, Valerio A, Tedesco L, et al. Exercise training induces mitochondrial biogenesis and glucose uptake in subcutaneous adipose tissue through eNOS-dependent mechanisms. Diabetes 2014;63(8):2800-11.

[33] Vettor R, Valerio A, Ragni M, Trevellin E, Granzotto M, Olivieri M, et al. Exercise training boosts eNOSdependent mitochondrial biogenesis in mouse heart: role in adaptation of glucose metabolism. Am J Physiol Endocrinol Metab 2014;306(5):E519-28.

[34] Chen JQ, Huang YY, Gusdon AM, Qu S. Irisin: a new molecular marker and target in metabolic disorder. Lipids Health Dis 2015;14:2.

[35] Bluher M, Michael MD, Peroni OD, Ueki K, Carter N, Kahn BB, et al. Adipose tissue selective insulin receptor knockout protects against obesity and obesity-related glucose intolerance. Dev Cell 2002;3(1):25-38.

[36] Heinonen S, Buzkova J, Muniandy M, Kaksonen R, Ollikainen M, Ismail K, et al. Impaired Mitochondrial Biogenesis in Adipose Tissue in Acquired Obesity. Diabetes 2015;64(9):3135-45.

[37] Aguiari P, Leo S, Zavan B, Vindigni V, Rimessi A, Bianchi K, et al. High glucose induces adipogenic differentiation of muscle-derived stem cells. Proc Natl Acad Sci U S A 2008;105(4):1226-31.

[38] Romacho T, Elsen M, Rohrborn D, Eckel J. Adipose tissue and its role in organ crosstalk. Acta Physiol (Oxf) 2014;210(4):733-53.

[39] Cusi K. Role of obesity and lipotoxicity in the development of nonalcoholic steatohepatitis: pathophysiology and clinical implications. Gastroenterology 2012;142(4):711-25 e6.

[40] Ma J, Fox CS, Jacques PF, Speliotes EK, Hoffmann U, Smith CE, et al. Sugar-sweetened beverage, diet soda, and fatty liver disease in the Framingham Heart Study cohorts. J Hepatol 2015;63(2):462-9.

[41] Parnell JA, Raman M, Rioux KP, Reimer RA. The potential role of prebiotic fibre for treatment and management of non-alcoholic fatty liver disease and associated obesity and insulin resistance. Liver Int 2012;32(5):701-11.

[42] Donath MY, Shoelson SE. Type 2 diabetes as an inflammatory disease. Nat Rev Immunol 2011;11(2):98-107.

[43] Stefan N, Haring HU. The role of hepatokines in metabolism. Nat Rev Endocrinol 2013;9(3):144-52.

[44] Bergheim I, Weber S, Vos M, Kramer S, Volynets V, Kaserouni S, et al. Antibiotics protect against fructoseinduced hepatic lipid accumulation in mice: role of endotoxin. J Hepatol 2008;48(6):983-92.

[45] Lim JS, Mietus-Snyder M, Valente A, Schwarz JM, Lustig RH. The role of fructose in the pathogenesis of NAFLD and the metabolic syndrome. Nat Rev Gastroenterol Hepatol 2010;7(5):251-64.

[46] Spruss A, Kanuri G, Wagnerberger S, Haub S, Bischoff SC, Bergheim I. Toll-like receptor 4 is involved in the development of fructose-induced hepatic steatosis in mice. Hepatology 2009;50(4):1094-104.

[47] Ritze Y, Bardos G, D'Haese JG, Ernst B, Thurnheer M, Schultes B, et al. Effect of high sugar intake on glucose transporter and weight regulating hormones in mice and humans. PLoS One 2014;9(7):e101702.

[48] Mozaffarian D, Hao T, Rimm EB, Willett WC, Hu FB. Changes in diet and lifestyle and long-term weight gain in women and men. N Engl J Med 2011;364(25):2392-404. 
[49] Rosqvist F, Iggman D, Kullberg J, Cedernaes J, Johansson HE, Larsson A, et al. Overfeeding polyunsaturated and saturated fat causes distinct effects on liver and visceral fat accumulation in humans. Diabetes 2014;63(7):2356-68. [50] Rival T, Cinq-Frais C, Silva-Sifontes S, Garcia J, Riu B, Salvayre R, et al. Alteration of plasma phospholipid fatty acid profile in patients with septic shock. Biochimie 2013;95(11):2177-81.

[51] Ferramosca A, Zara V. Modulation of hepatic steatosis by dietary fatty acids. World J Gastroenterol 2014;20(7):1746-55.

[52] Esposito K, Maiorino MI, Ciotola M, Di Palo C, Scognamiglio P, Gicchino M, et al. Effects of a Mediterraneanstyle diet on the need for antihyperglycemic drug therapy in patients with newly diagnosed type 2 diabetes: a randomized trial. Ann Intern Med 2009;151(5):306-14.

[53] Ryan MC, Itsiopoulos C, Thodis T, Ward G, Trost N, Hofferberth S, et al. The Mediterranean diet improves hepatic steatosis and insulin sensitivity in individuals with non-alcoholic fatty liver disease. J Hepatol 2013;59(1):138-43.

[54] Pallauf K, Giller K, Huebbe P, Rimbach G. Nutrition and healthy ageing: calorie restriction or polyphenol-rich "MediterrAsian" diet? Oxid Med Cell Longev 2013;2013:707421.

[55] Hsu CC, Jhang HR, Chang WT, Lin CH, Shin SJ, Hwang SJ, et al. Associations between dietary patterns and kidney function indicators in type 2 diabetes. Clin Nutr 2014;33(1):98-105.

[56] Elizondo A, Araya J, Rodrigo R, Poniachik J, Csendes A, Maluenda F, et al. Polyunsaturated fatty acid pattern in liver and erythrocyte phospholipids from obese patients. Obesity (Silver Spring) 2007;15(1):24-31.

[57] Pachikian BD, Essaghir A, Demoulin JB, Neyrinck AM, Catry E, De Backer FC, et al. Hepatic n-3 polyunsaturated fatty acid depletion promotes steatosis and insulin resistance in mice: genomic analysis of cellular targets. PLoS One 2011;6(8):e23365.

[58] Ritze Y, Bardos G, Claus A, Ehrmann V, Bergheim I, Schwiertz A, et al. Lactobacillus rhamnosus GG protects against non-alcoholic fatty liver disease in mice. PLoS One 2014;9(1):e80169.

[59] Ma YY, Li L, Yu CH, Shen Z, Chen LH, Li YM. Effects of probiotics on nonalcoholic fatty liver disease: a metaanalysis. World J Gastroenterol 2013;19(40):6911-8.

[60] Cani PD, Osto M, Geurts L, Everard A. Involvement of gut microbiota in the development of low-grade inflammation and type 2 diabetes associated with obesity. Gut Microbes 2012;3(4):279-88.

[61] Kobyliak N, Conte C, Cammarota G, Haley AP, Styriak I, Gaspar L, et al. Probiotics in prevention and treatment of obesity: a critical view. Nutr Metab (Lond) 2016;13:14.

[62] Mekkes MC, Weenen TC, Brummer RJ, Claassen E. The development of probiotic treatment in obesity: a review. Benef Microbes 2014;5(1):19-28.

[63] Papathanasopoulos A, Camilleri M. Dietary fiber supplements: effects in obesity and metabolic syndrome and relationship to gastrointestinal functions. Gastroenterology 2010;138(1):65-72 e1-2.

[64] Patrone V, Vajana E, Minuti A, Callegari ML, Federico A, Loguercio C, et al. Postoperative changes in fecal bacterial communities and fermentation products in obese patients undergoing bilio-intestinal bypass. Front Microbiol 2016;7:200.

[65] Yang PJ, Yang WS, Nien HC, Chen CN, Lee PH, Yu LC, et al. Duodenojejunal Bypass Leads to Altered Gut Microbiota and Strengthened Epithelial Barriers in Rats. Obes Surg 2015.

[66] Tonucci LB, Olbrich Dos Santos KM, Licursi de Oliveira L, Rocha Ribeiro SM, Duarte Martino HS. Clinical application of probiotics in type 2 diabetes mellitus: A randomized, double-blind, placebo-controlled study. Clin Nutr 2015.

[67] Asemi Z, Khorrami-Rad A, Alizadeh SA, Shakeri H, Esmaillzadeh A. Effects of synbiotic food consumption on metabolic status of diabetic patients: a double-blind randomized cross-over controlled clinical trial. Clin Nutr 2014;33(2):198-203.

[68] Beserra BT, Fernandes R, do Rosario VA, Mocellin MC, Kuntz MG, Trindade EB. A systematic review and metaanalysis of the prebiotics and synbiotics effects on glycaemia, insulin concentrations and lipid parameters in adult patients with overweight or obesity. Clin Nutr 2015;34(5):845-58.

[69] Park DY, Ahn YT, Park SH, Huh CS, Yoo SR, Yu R, et al. Supplementation of Lactobacillus curvatus HY7601 and Lactobacillus plantarum KY1032 in diet-induced obese mice is associated with gut microbial changes and reduction in obesity. PLoS One 2013;8(3):e59470.

[70] Chen J, Wang R, Li XF, Wang RL. Bifidobacterium adolescentis supplementation ameliorates visceral fat accumulation and insulin sensitivity in an experimental model of the metabolic syndrome. Br J Nutr 2012;107(10):1429-34. 
[71] Ivey KL, Hodgson JM, Kerr DA, Lewis JR, Thompson PL, Prince RL. The effects of probiotic bacteria on glycaemic control in overweight men and women: a randomised controlled trial. Eur J Clin Nutr 2014;68(4):447-52.

[72] Teff KL, Elliott SS, Tschop M, Kieffer TJ, Rader D, Heiman M, et al. Dietary fructose reduces circulating insulin and leptin, attenuates postprandial suppression of ghrelin, and increases triglycerides in women. J Clin Endocrinol Metab 2004;89(6):2963-72.

[73] Chiu S, Sievenpiper JL, de Souza RJ, Cozma Al, Mirrahimi A, Carleton AJ, et al. Effect of fructose on markers of non-alcoholic fatty liver disease (NAFLD): a systematic review and meta-analysis of controlled feeding trials. Eur J Clin Nutr 2014;68(4):416-23.

[74] Thuy S, Ladurner R, Volynets V, Wagner S, Strahl S, Konigsrainer A, et al. Nonalcoholic fatty liver disease in humans is associated with increased plasma endotoxin and plasminogen activator inhibitor 1 concentrations and with fructose intake. J Nutr 2008;138(8):1452-5.

[75] Garcia-Rodriguez CE, Mesa MD, Olza J, Buccianti G, Perez M, Moreno-Torres R, et al. Postprandial glucose, insulin and gastrointestinal hormones in healthy and diabetic subjects fed a fructose-free and resistant starch type IV-enriched enteral formula. Eur J Nutr 2013;52(6):1569-78.

[76] Bidwell AJ, Fairchild TJ, Wang L, Keslacy S, Kanaley JA. Effect of increased physical activity on fructose-induced glycemic response in healthy individuals. Eur J Clin Nutr 2014;68(9):1048-54.

[77] Whitehead A, Beck EJ, Tosh S, Wolever TM. Cholesterol-lowering effects of oat beta-glucan: a meta-analysis of randomized controlled trials. Am J Clin Nutr 2014;100(6):1413-21.

[78] Threapleton DE, Greenwood DC, Evans CE, Cleghorn CL, Nykjaer C, Woodhead C, et al. Dietary fibre intake and risk of cardiovascular disease: systematic review and meta-analysis. BMJ 2013;347:f6879.

[79] Summary of Revisions: Standards of Medical Care in Diabetes-2016. Diabetes Care 2016;39 Suppl 1:S4-5.

[80] American Diabetes A. Standards of medical care in diabetes--2014. Diabetes Care 2014;37 Suppl 1:S14-80.

[81] Mann JI, De Leeuw I, Hermansen K, Karamanos B, Karlstrom B, Katsilambros N, et al. Evidence-based nutritional approaches to the treatment and prevention of diabetes mellitus. Nutr Metab Cardiovasc Dis 2004;14(6):373-94.

[82] IDF Clinical Guidelines Taskforce, Ceriello A, Barakat M, Bahendeka S, Colagiuri S, Gerich J, et al. IDF 2011 Postmeal glucose guidelines. 2014; www.idf.org. Accessed Mar 28, 2016.

[83] National Institute for Health and Care Excellence (NICE) NG17. Type 1 diabetes in adults: diagnosis and management. 2015.

[84] Inzucchi SE, Bergenstal RM, Buse JB, Diamant M, Ferrannini E, Nauck M, et al. Management of hyperglycaemia in type 2 diabetes: a patient-centered approach. Position statement of the American Diabetes Association (ADA) and the European Association for the Study of Diabetes (EASD). Diabetologia 2012;55(6):1577-96.

[85] Inzucchi SE, Bergenstal RM, Buse JB, Diamant M, Ferrannini E, Nauck M, et al. Management of hyperglycaemia in type 2 diabetes, 2015: a patient-centred approach. Update to a position statement of the American Diabetes Association and the European Association for the Study of Diabetes. Diabetologia 2015;58(3):429-42.

[86] National Institute for Health and Care Excellence (NICE) NG28. Type 2 diabetes in adults: management. 2015. [87] Umpierrez GE, Hellman R, Korytkowski MT, Kosiborod M, Maynard GA, Montori VM, et al. Management of hyperglycemia in hospitalized patients in non-critical care setting: an Endocrine Society Clinical Practice Guideline. J Clin Endocrinol Metab 2012;97(1):16-38.

[88] Ichai C, Preiser JC, Societe Francaise dA-R, Societe de Reanimation de langue F, Experts g. International recommendations for glucose control in adult non diabetic critically ill patients. Crit Care 2010;14(5):R166.

[89] McClave SA, Taylor BE, Martindale RG, Warren MM, Johnson DR, Braunschweig C, et al. Guidelines for the provision and assessment of nutrition support therapy in the adult critically ill patient: Society of Critical Care Medicine (SCCM) and American Society for Parenteral and Enteral Nutrition (A.S.P.E.N.). JPEN J Parenter Enteral Nutr 2016;40(2):159-211.

[90] Bogun M, Inzucchi SE. Inpatient management of diabetes and hyperglycemia. Clin Ther 2013;35(5):724-33. [91] Berger MM, Mechanick Jl. Continuing controversy in the intensive care unit: why tight glycemic control, nutrition support, and nutritional pharmacology are each necessary therapeutic considerations. Curr Opin Clin Nutr Metab Care 2010;13(2):167-9.

[92] Davidson P, Kwiatkowski CA, Wien M. Management of hyperglycemia and enteral nutrition in the hospitalized patient. Nutr Clin Pract 2015;30(5):652-9.

[93] Ojo O, Brooke J. Evaluation of the role of enteral nutrition in managing patients with diabetes: a systematic review. Nutrients 2014;6(11):5142-52. 
[94] Holub I, Gostner A, Theis S, Nosek L, Kudlich T, Melcher R, et al. Novel findings on the metabolic effects of the low glycaemic carbohydrate isomaltulose (Palatinose). Br J Nutr 2010;103(12):1730-7.

[95] Hofman Z, van Drunen JD, de Later C, Kuipers H. The effect of different nutritional feeds on the postprandial glucose response in healthy volunteers and patients with type II diabetes. Eur J Clin Nutr 2004;58(11):1553-6. [96] Lee H, Koh SO, Park MS. Higher dextrose delivery via TPN related to the development of hyperglycemia in nondiabetic critically ill patients. Nutr Res Pract 2011;5(5):450-4.

[97] Alish CJ, Garvey WT, Maki KC, Sacks GS, Hustead DS, Hegazi RA, et al. A diabetes-specific enteral formula improves glycemic variability in patients with type 2 diabetes. Diabetes Technol Ther 2010;12(6):419-25. [98] Ceriello A, Lansink M, Rouws CH, van Laere KM, Frost GS. Administration of a new diabetes-specific enteral formula results in an improved $24 \mathrm{~h}$ glucose profile in type 2 diabetic patients. Diabetes Res Clin Pract 2009;84(3):259-66.

[99] McMahon MM, Nystrom E, Braunschweig C, Miles J, Compher C, American Society for P, et al. A.S.P.E.N. clinical guidelines: nutrition support of adult patients with hyperglycemia. JPEN J Parenter Enteral Nutr 2013;37(1):23-36.

[100] Mesejo A, Montejo-Gonzalez JC, Vaquerizo-Alonso C, Lobo-Tamer G, Zabarte-Martinez M, Herrero-Meseguer $\mathrm{JI}$, et al. Diabetes-specific enteral nutrition formula in hyperglycemic, mechanically ventilated, critically ill patients: a prospective, open-label, blind-randomized, multicenter study. Crit Care 2015;19:390.

[101] Vaisman N, Lansink M, Rouws CH, van Laere KM, Segal R, Niv E, et al. Tube feeding with a diabetes-specific feed for 12 weeks improves glycaemic control in type 2 diabetes patients. Clin Nutr 2009;28(5):549-55.

[102] Vanschoonbeek K, Lansink M, van Laere KM, Senden JM, Verdijk LB, van Loon LJ. Slowly digestible carbohydrate sources can be used to attenuate the postprandial glycemic response to the ingestion of diabetesspecific enteral formulas. Diabetes Educ 2009;35(4):631-40.

[103] Sato H, Carvalho G, Sato T, Lattermann R, Matsukawa T, Schricker T. The association of preoperative glycemic control, intraoperative insulin sensitivity, and outcomes after cardiac surgery. J Clin Endocrinol Metab 2010;95(9):4338-44.

[104] Gustafsson UO, Scott MJ, Schwenk W, Demartines N, Roulin D, Francis N, et al. Guidelines for perioperative care in elective colonic surgery: Enhanced Recovery After Surgery (ERAS ${ }^{\circledR}$ ) Society recommendations. World J Surg 2013;37(2):259-84.

[105] Braga M, Wischmeyer PE, Drover J, Heyland DK. Clinical evidence for pharmaconutrition in major elective surgery. JPEN J Parenter Enteral Nutr 2013;37(5 Suppl):66S-72S.

[106] Duncan AE. Hyperglycemia and perioperative glucose management. Curr Pharm Des 2012;18(38):6195-203. [107] Ljungqvist O. ERAS--enhanced recovery after surgery: moving evidence-based perioperative care to practice. JPEN J Parenter Enteral Nutr 2014;38(5):559-66.

[108] Li C, Carli F, Lee L, Charlebois P, Stein B, Liberman AS, et al. Impact of a trimodal prehabilitation program on functional recovery after colorectal cancer surgery: a pilot study. Surg Endosc 2013;27(4):1072-82.

[109] Scott MJ, Baldini G, Fearon KC, Feldheiser A, Feldman LS, Gan TJ, et al. Enhanced Recovery After Surgery (ERAS) for gastrointestinal surgery, part 1: pathophysiological considerations. Acta Anaesthesiol Scand 2015;59(10):1212-31.

[110] Egi M, Finfer S, Bellomo R. Glycemic control in the ICU. Chest 2011;140(1):212-20.

[111] Investigators N-SS, Finfer S, Chittock DR, Su SY, Blair D, Foster D, et al. Intensive versus conventional glucose control in critically ill patients. N Engl J Med 2009;360(13):1283-97.

[112] van den Berghe G, Wouters P, Weekers F, Verwaest C, Bruyninckx F, Schetz M, et al. Intensive insulin therapy in critically ill patients. N Engl J Med 2001;345(19):1359-67.

[113] Farrokhi F, Chandra P, Smiley D, Pasquel FJ, Peng L, Newton CA, et al. Glucose variability is an independent predictor of mortality in hospitalized patients treated with total parenteral nutrition. Endocr Pract 2014;20(1):41-5. [114] Krinsley JS. Glycemic variability and mortality in critically ill patients: the impact of diabetes. J Diabetes Sci Technol 2009;3(6):1292-301.

[115] Mesotten D, Preiser JC, Kosiborod M. Glucose management in critically ill adults and children. Lancet Diabetes Endocrinol 2015;3(9):723-33.

[116] Chan MC, Tseng JS, Hsu KH, Shih SJ, Yi CY, Wu CL, et al. A minimum blood glucose value less than or equal to $120 \mathrm{mg} / \mathrm{dL}$ under glycemic control is associated with increased 14-day mortality in nondiabetic intensive care unit patients with sepsis and stress hyperglycemia. J Crit Care 2016;34:69-73. 
[117] Ummu K. Jamaludin PDD, J. Geoffrey Chase, Aaron Le Compte, Geoffrey M. Shaw, Thomas Desaive, JeanCharles Preiser. Observation of incretin effects during enteral feed transitions of critically ill patients. Clinical Nutrition ESPEN 2012;7(4):e154-e9.

[118] Nielsen ST, Janum S, Krogh-Madsen R, Solomon TP, Moller K. The incretin effect in critically ill patients: a case-control study. Crit Care 2015;19:402.

[119] Petrov MS, Zagainov VE. Influence of enteral versus parenteral nutrition on blood glucose control in acute pancreatitis: a systematic review. Clin Nutr 2007;26(5):514-23. based or lipid-based parenteral nutrition on glucose metabolism, de novo lipogenesis, and respiratory gas exchanges in critically ill patients. Crit Care Med 1998;26(5):860-7.

[122] Singer P, Hiesmayr M, Biolo G, Felbinger TW, Berger MM, Goeters C, et al. Pragmatic approach to nutrition in the ICU: expert opinion regarding which calorie protein target. Clin Nutr 2014;33(2):246-51.

[123] Thorell A, Rooyackers O, Myrenfors P, Soop M, Nygren J, Ljungqvist OH. Intensive insulin treatment in critically ill trauma patients normalizes glucose by reducing endogenous glucose production. J Clin Endocrinol Metab 2004;89(11):5382-6.

[124] Krinsley JS, Grover A. Severe hypoglycemia in critically ill patients: risk factors and outcomes. Crit Care Med 2007;35(10):2262-7.

[125] Vriesendorp TM, van Santen S, DeVries JH, de Jonge E, Rosendaal FR, Schultz MJ, et al. Predisposing factors for hypoglycemia in the intensive care unit. Crit Care Med 2006;34(1):96-101.

[126] Preiser JC, Devos P, Ruiz-Santana S, Melot C, Annane D, Groeneveld J, et al. A prospective randomised multicentre controlled trial on tight glucose control by intensive insulin therapy in adult intensive care units: the Glucontrol study. Intensive Care Med 2009;35(10):1738-48. 